Arch. histol. jap. Vol. 32, No. 1 (1970)

p. $87-94$

Department of Anatomy (Prof. T. Setoguti), Gifu University School of Medicine,

Gifu, Japan

\title{
An Electron Microscopic Study on Neutrophil Leukocytes of the Toad, Bufo vulgaris japonicus
}

\author{
Takao Setoguti, Hiroyuki Fuji and Hideo Isono \\ （瀬戸口孝夫，藤 井寛 之，磯野日出夫）
}

Received March 23, 1970

Many reports have been published on the ultrastructure of neutrophil leukocytes. Most of these studies, however, involve mammals (KaUtZ and MARSH, 1954; PEASE, 1955, 1956; Braunsteiner and Pakesch, 1957; Watanabe, 1957; Anderson, 1966; Bainton and Farquhar, 1966; Watanabe, Donahue and Hoggatt, 1967; Wetzel et al., 1967; BRETON-GoRIUS, 1968; HIRSCH and FEDORKo, 1968) and only a few papers concern the other species (CAMPBelL, 1967, 1969).

The fine structure of amphibian blood cells is of interest from a phylogenetic point of view. The present study deals with the cytology of mature neutrophil leukocytes of the toad, Bufo vulgaris japonicus.

\section{Materials and Methods}

The venous blood from the portal vein of the adult toad, Bufo vulgaris japcnicus, was cellected in a syringe which contained an anticoagulant of $5 \%$ sodium citrate equal to $1 / 5$ of the volume of blood. After centrifugation at room temperature for 10 min at $5,000-10,000 \mathrm{~g}$, the supernatant plasma was discarded and $3 \%$ glutaraldehyde buffered to $\mathrm{pH} 7.4$ with $0.1 \mathrm{M}$ phosphate was added to the remaining blood cells (ANDERSON, 1965). These specimens were carefully placed in a refrigerator for $1 \mathrm{hr}$. The buffy coat obtained was cut in small pieces according to the method of WATANABE, Donahue and HogGatt (1967) and then washed for $30 \mathrm{~min}$ in three changes of $0.1 \mathrm{M}$ phosphate buffer containing $5 \%$ sucrose. Each piece of the specimens was. then postfixed in Millonig's solution containing $1 \% \mathrm{OsO}_{4}$ for $11 / 2 \mathrm{hrs}$, dehydrated in graded acetons and propylen oxide, and finally embedded in Epon 812. The sections: stained with uranyl acetate and lead acetate were examined with a JEM 6C.

On the other hand, part of the blood as well as small pieces of the lung and spleen tissues were directly fixed in Millonig's solution containing $1 \% \mathrm{OsO}_{4}$ and routinely made to preparations for electron microscopy. As a control, the smear preparation of the blood was stained with Giemsa's fluid and observed under the light microscope.

\section{Observations}

The toad neutrophils obtained by means of centrifugation of the blood usually are round or oval and rarely irregular in shape (Fig. 1). They are less than $13 \mu$ in diameter. The cells contained in blood vessels, however, more frequently show irregular outlines. The neutrophils extrude microvilli-like protrusions, measuring up to $4 \mu$ in length and $0.06 \mu$ in breadth, from the peripheral cytoplasm. Occasional 
cells, especially those in the blood vessels, usually have several other thick processes, too.

The nucleus is polymorphic or lobulated and generally deeply indented, being eccentrically located in the cell body (Fig. 1). The nucleoplasm is electron dense in the periphery, but is less dense in the central area, and the latter area has several chromatin-dense regions. The nucleolus is not encountered in any sections.

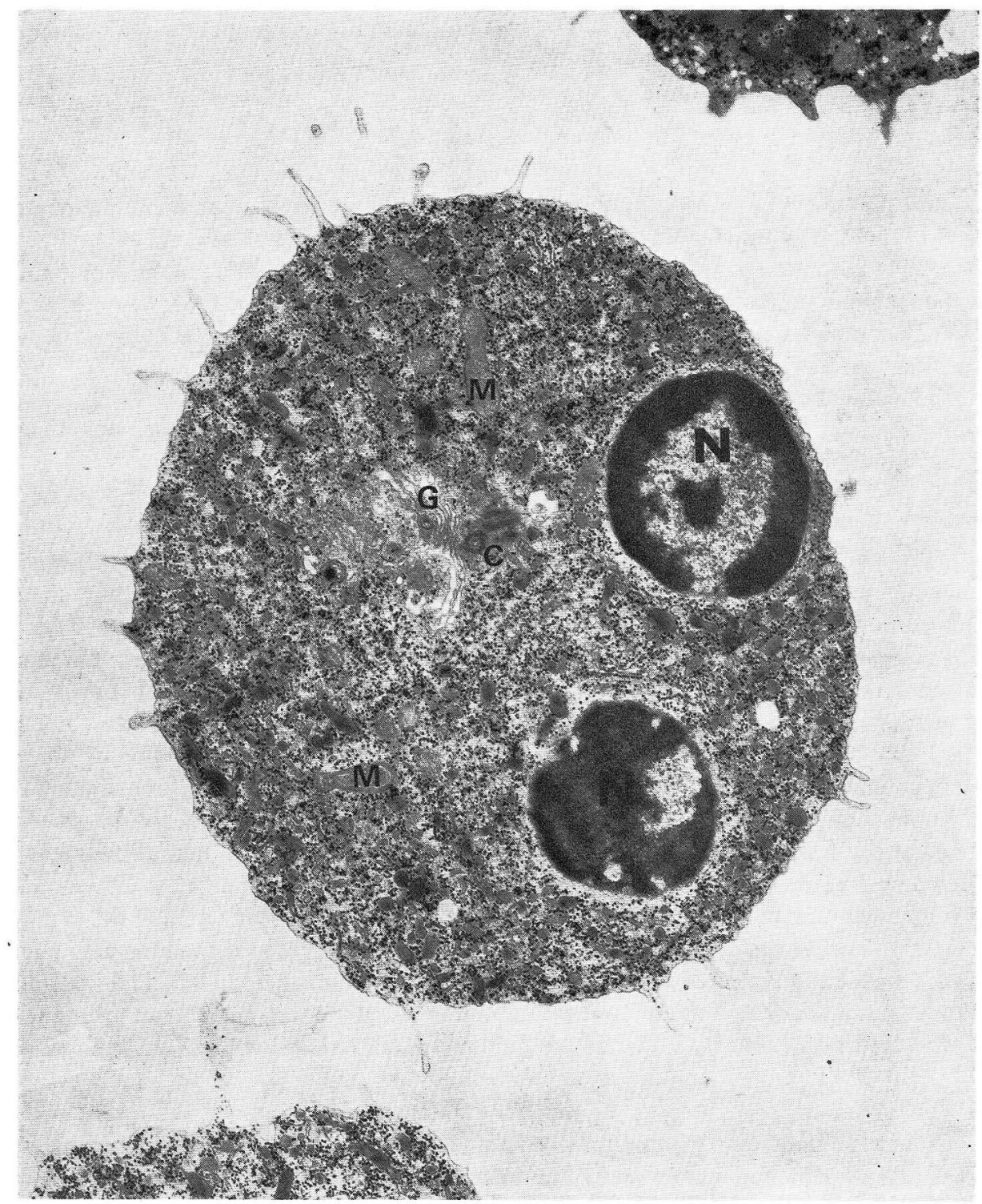

Fig. 1. A toad neutrophil at a low magnification showing relatively large amount of glycogen granules distributed throughout the cytoplasm. $C$ centrioles and their associated satellites, $G$ Golgi apparatus, $M$ mitochondria, $N$ nucleus. Glutaraldehyde-osmium tetroxide fixation. $\quad \times 11,800$ 
The cytoplasmic matrix is denser in glutaraldehyde-fixed preparations than in $\mathrm{OsO}_{4}$-fixed ones. The mitochondria are round to rod-shaped in profile and distributed sparsely throughout the cytoplasm (Fig. 1). Some of them display cristae running parallel to their long axis (Fig. 2). The Golgi complex is relatively small in size and consists of four to seven layers of flattened membranous cisternae and variable numbers of associated vacuoles or vesicles (Fig. 1, 3, 5). Agranular tubular vesicles are relatively numerous (Fig. 2, 3), being scattered throughout the cytoplasm, especially near the Golgi area (Fig. 3). They are usually seen mingled with specific granules and frequently appear to contain a moderately dense material (Fig. 2, 3). Some of these vesicles seem to be associated with the Golgi complex (Fig. 3).

The granular endoplasmic reticula are a few in number and distributed in groups rather in the peripheral portions of the cytoplasm. In each group, they are frequently arranged in long parallel cisternae (Fig. 3). In addition, several large vacuoles are sometimes seen in the cytoplasm (Fig. 2). Some of them contain a small amount of a dense, finely filamentous material and/or several vesicles (Fig. 2, 4).

Specific granules are distributed numerously and widely in the cytoplasm and bounded by a well-defined limiting membrane. They are, regardless of the fixative used, classified into mainly three types: large, dense, oval to elliptical granules less than $0.25 \mu$ in diameter and $0.7 \mu$ in length; medium-sized, variously dense, elongated

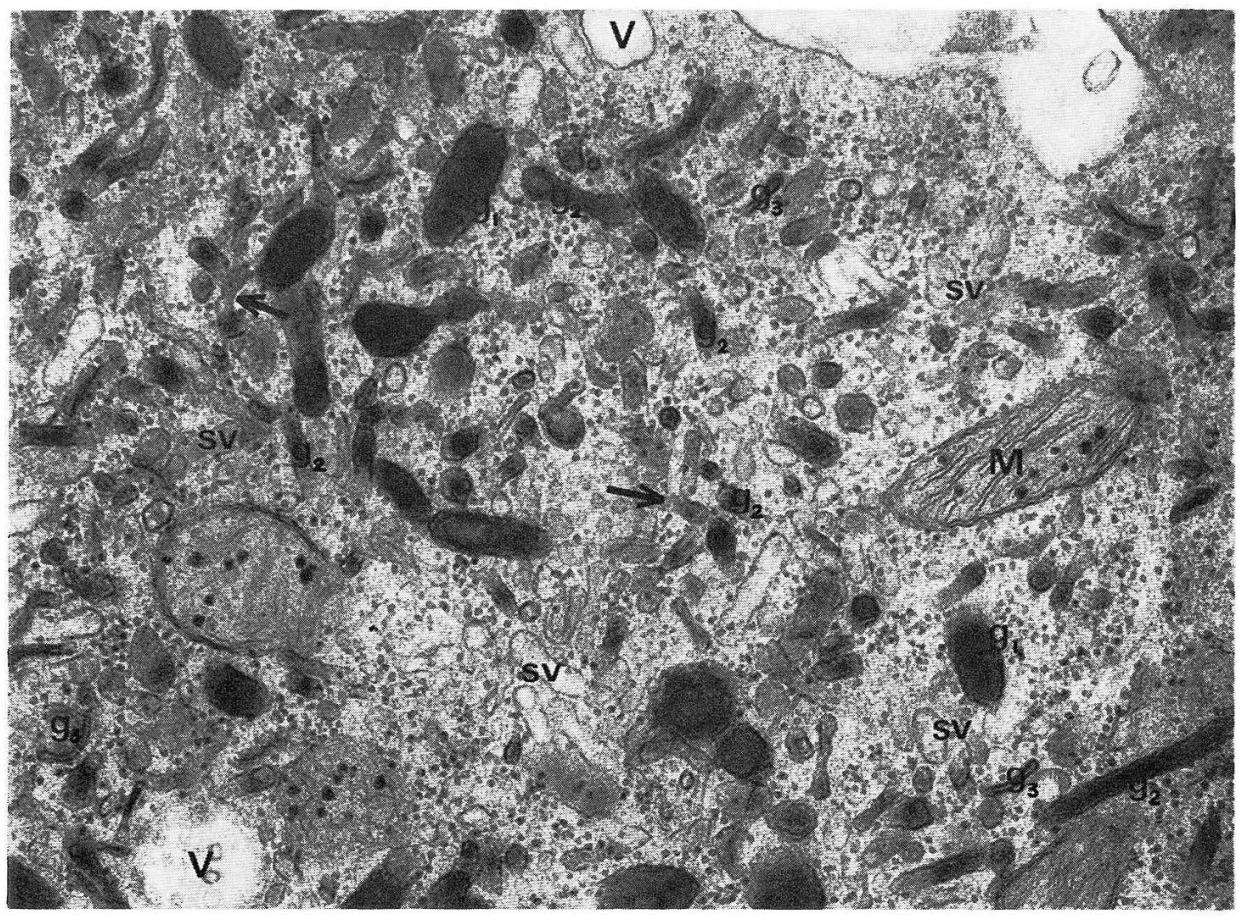

Fig. 2. Portion of the cytoplasm of a toad neutrophil at a higher magnification. Note transitional forms (arrows) between agranular tubular vesicles $(s v)$ and medium-sized, variously dense, elongated rod-like granules $\left(g_{2}\right)$. Toward the bottom left a semicircular, small granule with indistinct periodic bands can be seen. $g_{1}$ Large, dense, oval to elliptical granules, $g_{3}$ small, differently dense, club-like granules, $V$ large vacuoles. Glutaraldehyde-osmium tetroxide fixation. $\times 32,000$ 
rod-like granules usually about $0.07 \mu$ in width and less than $0.7 \mu$ in length; small, differently dense, club-like granules generally $0.03 \mu$ in width and $0.2 \mu$ in length.

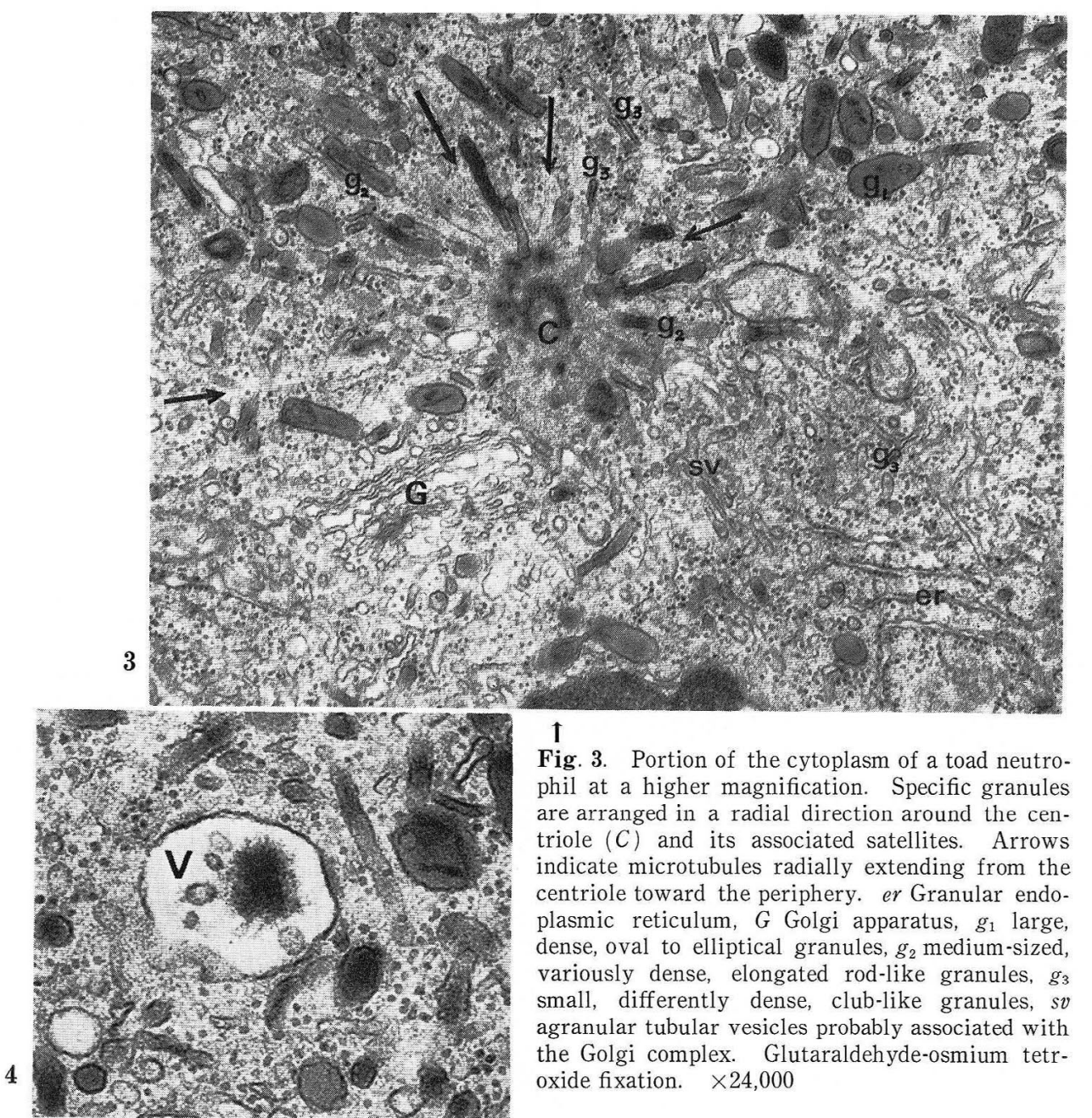

Fig. 4. Portion of the cytoplasm of a toad neutrophil at a higher magnification, showing a large vacuole containing a small amount of a dense, finely filamentous material and several vesicles $(V)$. Glutaralchehyde-osmium tetroxide fixation. $\times 40,000$

Some of the latter type granules seem to be slightly denser in limiting membrane than the other types (Fig. 2, 3). The first type granules sometimes contain either membranes often forming myelin figures or vesicle-like structures (Fig. 2, 3, 6). The second type granules frequently show denser regions along their long axis (Fig. $2,3,5)$. Accordingly, in cross section they have an appearance like cored vesicles (Fig. 5, 6, 7). The third type granules, small club-like ones, usually swell like a dumb-bell at both ends (Fig. 2, 3, 5, 7). Similar figures are sometimes observed also in the second type granules (Fig. 2,3). Some of the small club-like granules show 


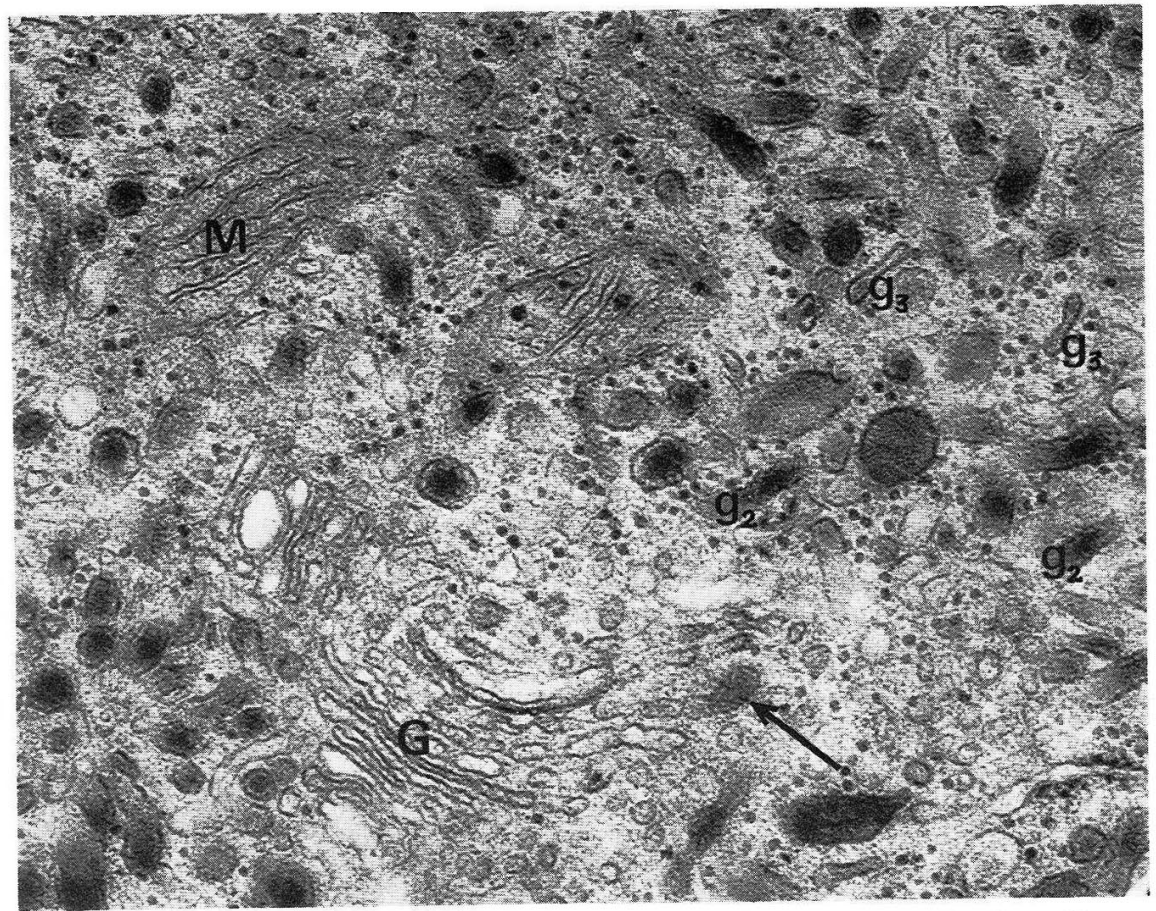

Fig. 5. Portion of the cytoplasm of a toad neutrophil at a higher magnification. Note a transitional form (arrow) between the dilated cisternae of the Golgi complex $(G)$ and the medium-sized, variously dense, elongated granules $\left(g_{2}\right) . g_{3}$ Small, differently dense, club-like granules. $M$ mitochondria. Glutaraldehyde-osmium tetroxide fixation. $\times 40,000$

Fig. 6. Portion of the cytoplasm of a toad neutrophil at a higher magnification. A large, dense, oval granule containing several vesicle-like structures $\left(g_{1}\right)$ and cross-sectioned, medium-sized, elongated rod-like granules appearing as cored vesicles $\left(g_{2}\right)$. Glutaraldehyde-osmium tetroxide fixation. $\times 40,000$

Fig. 7. Portion of the cytoplasm of a toad neutrophil. Arrows indicate small, club-like granules showing indistinct periodic bands along their long axis. $g_{1}$ Large, dense, oval granule, $g_{2}$ cross-sectioned, medium-sized, elongated rod-like granules appearing as cored vesicles. Glutaraldehyde-osmium tetroxide fixation. $\times 40,000$

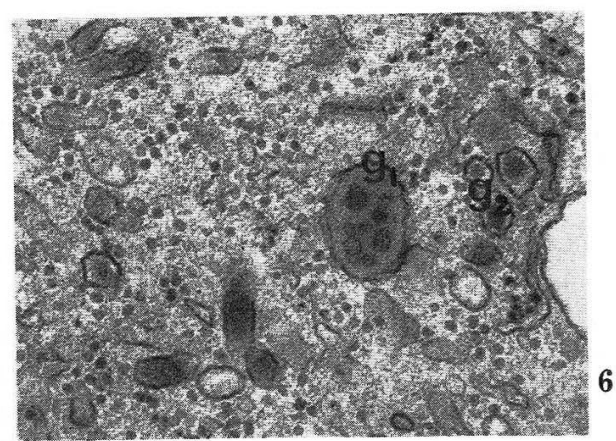

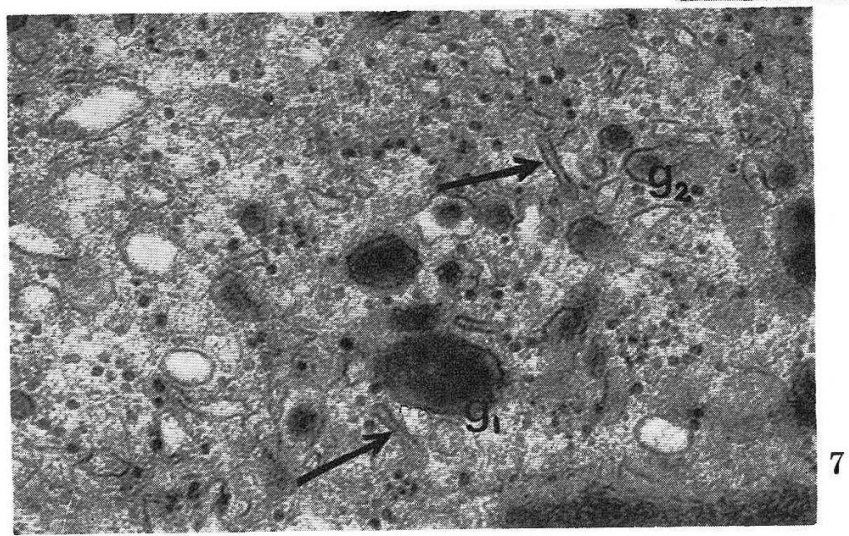


indistinct periodic bands along their long axis (Fig. 2, 7). A few of the third type granules are bent in the form of a semicircle (Fig. 2).

The cytocentrum is located near the center of the cytoplasm partially surrounded by the lobes of the nucleus. It is composed of two centrioles and their associated satellites (Fig. 1, 3). In some of the sections cut in a plane containing a centriole, large numbers of microtubules radially extending from the centriole toward the periphery are present in the cytoplasm (Fig. 3). In such cases, neighbouring specific granules are also arranged in a radial direction around the centriole. Relatively large amounts of glycogen granules are distributed throughout the cytoplasm (Fig. 1-7).

\section{Discussion}

Neutrophil leukocytes are light-microscopically characterized by the presence of neutrophilic granules in the cell body. Therefore, electron microscopic studies on neutrophils pay attention mainly to these granules and their development. As for mammalian neutrophils, early observations reported that neutrophils contain only one granule type. However, PeAse $(1955,1956)$ observed two different types of granules, WATANABE (1957) described granules of low density and granules of high density, and BAINTON and FARQUHAR (1966) classified such granules into dense, azurophilic granules and less dense, specific ones. Furthermore, ANDERson (1966), Wetzel, Horn and Spicer (1969) and Watanabe, Donahue, and Hoggatt (1967) distinguished three types of granules, and DAEMs (1968) observed even four types of granules.

On the other hand, the present authors observed mainly three types of granule in the mature neutrophils of the toad: large, dense, oval to elliptical granules; medium-sized, variously dense, elongated rod-like granules; small, differently dense, club-like granules. Of these three types of granules, however, there may be transitional forms in shape, size, and electron density between the first type and the second type granules. Therefore, the former are supposed to develop from the latter, probably with both increased dense material accumulated in the granules and related alteration of their outlines. However, large, less dense granules corresponding to socalled specific type observed in mammals were not encountered in the toad neutrophils. The smear preparation of toad blood, when stained with Giemsa's fluid, showed numerous reddish purple, azurophilic particles distributed widely in the cytoplasm, which are thought possibly to correspond to the large and medium-sized, dense granules seen under the electron microscope.

Furthermore, mingled with these three types of glanules, in and near the Golgi area were frequently observed large numbers of agranular tubular vesicles which are similar in shape and size and sometimes even in electron density to some of the medium-sized, rod-like granules (Fig. 2, 5). However, it could not be decided whether such vesicles belong mainly to the agranular endoplasmic reticulum or to the Golgi complex.

BAINTON and FARQUHAR (1966) suggested that azurophilic granules are originated from the concave face of the Golgi complex, while specific granules from the convex face, and Wetzel, HorN and SPICER (1967) confirmed most of their findings. Also in the toad neutrophils, it may be assumed, therefore, that some of the granules are derived from the Golgi complex. In this study, however, the intimate association of the Golgi complex and the granules was only occasionally demonstrated (Fig. 5), since 
the neutrophils observed were mature types and not immature ones such as seen in bone marrow by the authors mentioned above.

Concerning granule population except in mammals, CAMPBELL (1967) has electronmicroscopically found two populations of granules in neutrophilic myelocytes of the bone marrow of chickens and pigeons. In metamyelocytes, however, he has mainly been able to detect one population of dense, homogeneous, spindle-shaped bodies. Moreover, the same author (1969) has studied granulocytopoiesis in slender salamanders and has concluded that the mature or nearly mature neutrophils contain only one granule type.

In the present study, however, the small, club-like granules remarkably differ from the other two types of granules, in respect to size and shape. Such granules are thought to be never seen in the neutrophils of any species reported up to date. Neverthless, it can not be denied that these small granules are either transformed into medium-sized granules or only show profiles cut in such a direction that the latter resemble the former granules. Further studies on immature neutrophils such as myelocytes are necessary to reveal the problem of granule population in the toad.

In some cases, numerous microtubules radially surrounded the cytocentrum. Similar findings have been also reported by BAINTON and FARQUHAR (1966), BRETONGoRIUS (1968), and CAMPBELL (1969) in rabbits, man and slender salamanders, respectively. HIRSCH and FEDORKo (1968) have reported that in neutrophils cytoplasmic microtubules are found only in the cells fixed while engaged in locomotion.

\section{Summary}

The toad neutrophil leukocytes collected from the peripheral blood were studied under the electron microscope.

The cells usually are round or oval and have microvilli-like protrusions. The nucleus is polymorphic or lobulated, being eccentrically located in the cell body. In the cytoplasm, there are observed a few mitochondria and granular endoplasmic reticula, a relatively well-developed Golgi complex and agranular tubular vesicles, many specific granules, and a relatively large amount of glycogen granules.

Specific granules are classified into three types: large, dense, oval to elliptical granules; medium-sized, variously dense, elongated rod-like granules; small, differently dense, club-like granules. There are transitional forms between the first type and the second type granules and both these types are thought to correspond to azurophilic granules. To determine whether the third type granules belong to a different population or not was deferred in this study.

The cytocentrum and its associated microtubules are demonstrated in some cases.

\section{ガマの中性好性白血球の電子顕微鏡的研究（内容自抄）}

\section{ガマの末梢血の中性好性白血球が電子顕微鏡で観察された.}

細胞は遠沈して集めたものは通常 円形または卵円形で, 血管内のものはしばしば不 規則形を示す，核は多形核または分葉核で偏心性に位置する。胞体は微絨毛様突起を有 し，細胞形質内には 少数の糸粒体と粗面小胞体，発育のかなり良好なゴルジ装置と滑面 の小胞, 多数の特殊顆粒, かなり多量のグリコゲン顆粒が観察される.

特殊顆粒は次の 3 型に分類される：大型の電子密度の高い卵円形ないし楕円形の顆粒, 
中等大の種々の電子密度の伸長した桿状の顆粒, 小型の種々の電子密度の棍棒状の顆粒. 第 1 型と第 2 型の顆粒間には移行型が存在し, 前者は 後者の内部に暗調の物質の蓄積と それに伴う変形によって生じ，これら両型はギムザ染色所見よりアズール顆粒に相当す ることが推察される．第 3 型は従来の報告にみられない形態を示すが，はたして別な顆 粒集団に属するか否かの決定は本研究では保留された。

中心小体とそれに関連した微小管が証明された。

\section{References}

Anderson, D. R.: A method of preparing peripheral leukocytes for electron microscopy. J. Ultrastr. Res. 13: 263-268 (1965).

-: Ultrastructure of normal and leukemic leukocytes in human peripheral blood. J. Ultrastr. Res. Suppl. 9: 1-42 (1966).

Bainton, D. F. and M. G. Farquhar: Origin of granules in polymorphonuclear leukocytes. Two types derived from opposite faces of the Golgi complex in developing granulocytes. J. Cell Biol. 28: 277-301 (1966).

Braunsteiner, H. and F. Pakesch: Elektronenmikroskopische Uutersuchungen der Granula menschlicher Leukozyten. Acta Haematol. 17: 136-142 (1957).

Breton-Gorius, J.: Étude des leucocytes étalés par coupes sériées parallèles et perpendiculaires en plan d'étalement. J. Microsc. 7: 95-106 (1968).

Campbell, F.: Fine structure of the bone marrow of the chicken and pigeon. J. Morphol. 123: 405440 (1967).

Campbell, F. R.: Electron microscopic studies on granulocytopoiesis in the slender salamander Anat. Rec. 163: 427-447 (1969).

Daems, W. T.: On the fine structure of human neutrophilic leukocyte granules: J. Ultrastr. Res. 24: 343-348 (1968).

Hirsch, J. G. and M. Fedorko: Ultrastructure of human leukocytes after simultaneous fixation with glutaraldehyde and osmium tetroxide and "postfixation" in uranyl acetate. J. Cell Biol. 38: 615-627 (1968).

Kautz, J. and Q. B. De Marsh: An electron microscopic study of sectioned cells of peripheral blood and bone marrow. Blood 9: 24-38 (1954).

Pease, D. C.: Marrow cell seen with the electron microscope after ultrathin sectioning. Rev. d'Hematol. 10: 300-313 (1955). -: An electron microscopic study of red bone marrow. Blood 11: 501-526 (1956).

Watanabe, I., S. Donahue and N. Hoggatt: Method for electron microscopic studies of circulating human leukocytes and observations on their fine structure. J. Ultrastr. Res. 20: 366-382 (1967).

Watanabe, Y.: Observation of white blood cells with electron microscope. J. Electron Microsc. 5: 46-57 (1957).

Wetzel, B. K., R. G. Horn and S. S. Spicer: Fine structural studies on the development of heterophil, eosinophil, and basophil granulocytes in rabbits. Lab. Invest. 16: 349-382 (1967).

瀬戸口 孝 夫

厂500 岐阜市司町 40

岐阜大学医学部第一解剖学教室
Prof. Takao Setoguti

Department of Anatomy

Gifu University

School of Medicine

500 Gifu, Japan 